\title{
Surgical management of conjunctival nevi in children
}

\section{Leczenie chirurgiczne znamion spojówki u dzieci}

\author{
Klaudia Rakusiewicz, Krystyna Kanigowska, Wiesława Grajkowska, Wojciech Hautz \\ Department of Ophthalmology, Children's Memorial Health Institute \\ Head: Wojciech Hautz, MD, PhD
}

\begin{abstract}
Ahstract:
Aim: To analyse histological evaluation findings in children with conjunctival pigmented lesions.

Material and methods: A retrospective medical record analysis of patients with conjunctival pigmented lesions treated between 2009 and 2018 was carried out. The patients ( $n=145 ; 87$ males, 58 females) were aged 1 to 18 years (mean age of 10 years) underwent surgical treatment at the Department of Ophthalmology, at the Children's Memorial Health Institute.

Results: Out of 146 analysed conjunctival lesions, 132 (90.41\%) were conjunctival nevi. Histological evaluation findings were melanocytic nevus (61 eyes, 41.78\%), compound nevus (47 eyes; 32.19\%), junctional nevus (23 eyes;15.75\%) and subepithelial nevus ( 1 eye; $0.68 \%)$. The nevi were located in the bulbar conjunctiva (119 lesions, $81.51 \%$ ) and lacrimal caruncle (27 lesions, $18.49 \%)$. The lesions found in the bulbar conjunctiva were usually located temporally (77 eyes, 64.71\%) and nasally (42 eyes, 35.29\%). In 14 cases (9.59\%), the diagnosis of conjunctival pigmented lesion was ruled out with histology evaluation demonstrating inflammation ( 3 cases), inflammation with fibrosis (2 cases), melanosis (2 cases) as well as lentigo, subconjunctival haemorrhage, lymphangioma, haemangioma, severe conjunctival oedema with dilated lymphatic vessels, elevated melanocyte count and fibrotic connective tissue (one case of each).

Conclusions: Conjunctival lesions in children are mostly benign with conjunctival nevus being the most common finding of histological evaluation.

Key words: $\quad$ conjunctival nevi, conjunctival pigmented lesions, children, conjunctiva.

Abstrakt: $\quad$ Cel: analiza wyników histopatologicznych zmian barwnikowych spojówki u dzieci.

Materiał i metody: retrospektywna analiza pacjentów ze zmianami barwnikowymi spojówki w wieku od 1. roku życia do 18. roku życia, którzy zostali zakwalifikowani do leczenia chirurgicznego w Klinice Okulistyki IP CZD w latach 2009-2018.

Wyniki: przeanalizowano 146 zmian spojówki łącznie u 145 badanych (u 87 chłopców i u 58 dziewcząt, średnia wieku 10 lat), znamiona spojówki rozpoznano u 132 badanych z tej grupy (90,41 \%). Wyniki badania histopatologicznego wykazały: znamię melanocytarne - w 61 oczach (41,78\%), znamię złożone - w 47 oczach (32,19\%), znamię łączące - w 23 oczach (15,75\%), znamię podnabłonkowe - w 1 oku (0,68\%). Anatomicznie znamiona zlokalizowano: w spojówce gałkowej - 119 zmian (81,51\%), w mięsku łzowym - 27 zmian (18,49\%). Na spojówce gałkowej zmiany najczęściej były położone od skroni w 77 oczach $(64,71 \%)$, od nosa w 42 oczach $(35,29 \%)$. W 14 przypadkach $(9,59 \%)$ nie uzyskano rozpoznania znamienia barwnikowego spojówki, w wynikach histopatologicznych opisywano: proces zapalny - 3 przypadki, proces zapalny z włóknieniem - 2 przypadki, melanoza - 2 przypadki, pojedyncze przypadki takie jak plama soczewicowata, wylew krwi pod spojówkę, naczyniak chłonny, naczyniak krwionośny, silny obrzęk spojówki z poszerzonymi naczyniami chłonnymi, zwiększona liczba melanocytów, tkanka łączna włóknista.

Wnioski: Zmiany spojówki u dzieci mają zazwyczaj charakter łagodny, a w rozpoznaniu histopatologicznym najczęściej jest opisywane znamię spojówki.
\end{abstract}

Słowa kluczowe: znamię spojówki, zmiana barwnikowa spojówki, spojówka, znamię barwnikowe, dzieci.

The authors declare no conflict of interest/ Autorzy zgłaszają brak konfliktu interesów w związku z publikowaną pracą

\section{Introduction}

Conjunctival nevus is usually described as a benign lesion characterised by high clinical and histological variability. It manifests as a discrete, flat or elevated lesion with varied degrees of pigmentation (1). Shields et al. $(2,3)$ analysed a group of 410 patients and described dark pigmented lesions $(65 \%$ of cases), lightly coloured lesions (19\%) and colourless nodules (16\%). Several authors reported that conjunctival nevus is usually located in the bulbar conjunctiva and less frequently in the lacrimal caruncle, plica semilunaris or palpebral conjunctiva $(1,2,4,5)$.
The nevus becomes predominantly evident in childhood and usually remains stable over time $(1,4,6,7)$. Histologically, conjunctival nevus is a proliferation of melanocytes within the basal layer of the conjunctiva $(4,8)$ and its histological structure resembles the one of cutaneous nevi $(1,6,8)$. Therefore, the most common classification of pigmented conjunctival nevi is based on the categories used for classification of cutaneous lesions. In most publications, the authors distinguish three types of melanocytic conjunctival lesions i.e. junctional lesions (naevus junctionalis), compound lesions (naevus compositus) and 
subepithelial lesions (naevus subdermalis) $(1,4,8)$. The available sources do not describe any differences pertaining to management, prognosis and risk of neoplastic transformation based on the histological types of conjunctival nevi. The major clinical question related to conjunctival nevi refers to the risk of malignant transformation. Early stages of conjunctival melanoma may be clinically indistinguishable from benign lesions. However, the analysis of large patient groups indicated that the estimated risk of conjunctival nevus transformation into melanoma is below $1 \%(1,3,8,9)$. Melanoma is a malignant neoplasm derived from melanocytes. Janovic et al. (7) state that the eye is the most common non-cutaneous location of this neoplasm but conjunctival melanoma accounts for only $5 \%$ of all ocular melanomas. Whereas the incidence of conjunctival melanoma has increased by $295 \%$ over the last 27 years, the incidence of choroidal melanoma has remained unchanged. Among the postulated causes of the rising incidence, increased exposure to UV radiation in the recent years seems to be most likely (7). It is commonly agreed that conjunctival lesions are usually benign and the incidence of conjunctival melanoma in children is extremely low. Nevertheless, this type of neoplasm should not be underestimated due to its high level of malignancy $(7,9$, $10,11)$. This article discusses the results of a retrospective study in a group of children treated in the Department of Ophthalmology of the Children's Memorial Health Institute (Poland) between 2011 and 2018.

\section{Purpose}

To analyse histological evaluation findings in children with conjunctival pigmented lesions treated surgically for conjunctival lesions at the Department of Ophthalmology of the Children's Memorial Health Institute.

\section{Material and methods}

This retrospective study included an analysis of histological findings in 146 eyes of 145 patients aged 1 to 18 years with conjunctival lesions. In one case, the lesion was bilateral. The preliminary clinical diagnosis following ocular assessment was conjunctival pigmented nevus. In each case, the assessment included visual acuity, intraocular pressure (IOP) as well as anterior segment and fundus examination to check for potential concomitant pigmented lesions in other ocular structures. Candidates for surgical treatment were identified following a consultation with parents and considering their expectations. Indications for surgical intervention were changes in the shape or colour of the nevus, aesthetic aspects, as well as parental concerns and demands. A full thickness excision of an entire lesion with scleral exposure using a surgical microscope was performed in all patients under general anaesthesia. All blood vessels supplying the lesion were closed with diathermy prior to the incision. The conjunctival lesions were removed as part of a visually guided procedure together with a margin of healthy tissue and the wound margins were closed with Vicryl 8-0 single sutures. Directly following the surgery, anti-inflammatory ointment was administered to the surgical site and a dressing was applied. The post-operative treatment included topical steroid and antibiotic, which were continued for two weeks. In each case, the removed tissue was sent to the Pathology Lab at the Children's Memorial Health Institute for histological evaluation. Following the surgery, most patients had conjunctival oedema and congestion. There was one case of conjunctival hypertrophy and scarring at the surgical site, which required surgical correction for aesthetic considerations. There was no recurrence. Clinical data including lesion location, patient age and gender were ascertained from the medical records.

\section{Results}

A total of 146 eyes of 145 patients ( 87 males, $60.00 \%$ and 58 females, $40.00 \%$ ) were enrolled (there was one case of bilateral lesion). The youngest patient was 18 months old and the oldest one was 17 years and 11 months old (mean age of 10 years). There were $70(47.95 \%)$ lesions located in the right eye and $76(52.05 \%)$ lesions located in the left eye. There were $119(81.51 \%)$ bulbar conjunctival lesions, more often situated temporally (77 lesions, $64.71 \%$ ) rather than nasally (42 lesions, $35.29 \%)$. The remaining $27(18.49 \%)$ lesions were located in the lacrimal caruncle, more often in the left (15 cases, $55.56 \%)$ rather than the right eye (12 cases, $44.44 \%$ ). There were no nevi located within the palpebral conjunctiva, conjunctival fornix or the perilimbal region. The histological evaluation confirmed that all lesions were benign without the features of malignant transformation. There was no case of conjunctival melanoma or concomitant pigmented lesion in other ocular structures outside the conjunctiva. The vast majority $(90.41 \%)$ of lesions were identified as conjunctival nevi including melanocytic (61 eyes, 41.78\%) (Fig. 1), compound (47 eyes, 32.19\%) (Fig. 2), junctional (23 eyes, 15.75\%) (Fig. 3) and subepithelial (1 eye, 0.68\%) nevi. In 14 cases $(9.59 \%)$, there was melanocyte growth or atypical cells. In this group, histological findings included inflammation (3 lesions), inflammation with fibrosis (2 lesions) and melanosis (2 lesions in 1 patient - bilateral). There were single cases of lentigo (lentigo simplex), subcutaneous haemorrhage, lymphangioma, haemangioma, significant conjunctival oedema with dilated lymph vessels, increased melanocyte count and fibrotic connective tissue. For the purposes of this study, those lesions were therefore included in the "Other" category. Table I shows the distribution of conjunctival lesion types in the study group.

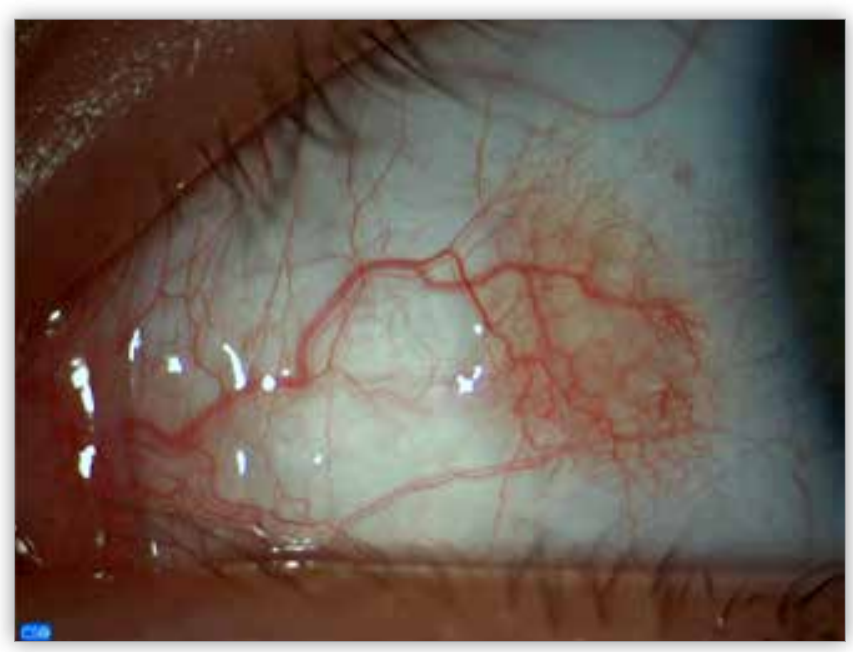

Fig. 1. Melanocytic nevus of bulbar conjunctiva in a 5-year-old boy. Ryc. 1. Znamię melanocytarne spojówki gałkowej u 5-letniego chłopca. 


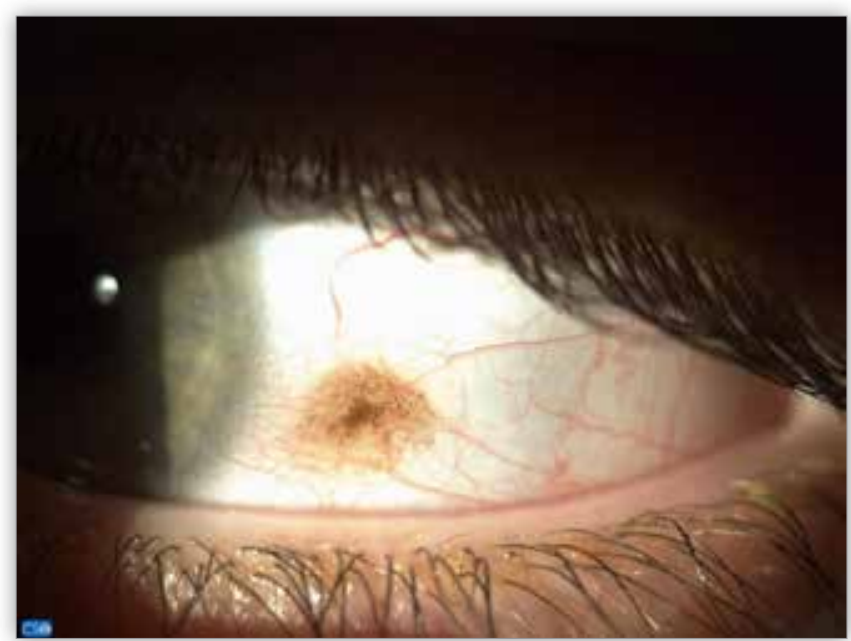

Fig. 2. Compound nevus of bulbar conjunctiva in a 10 -year-old boy. Ryc. 2. Znamię złożone spojówki gałkowej u 10-letniego chłopca.

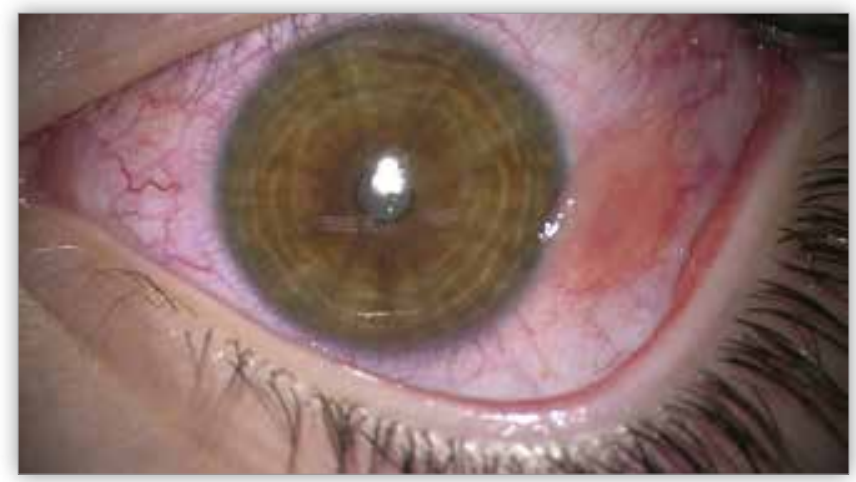

Fig. 3. Junctional nevus of bulbar conjunctiva with limbal involvement in a 12-year-old girl.

Ryc. 3. Znamię łączące spojówki gałkowej u 12-letniej dziewczynki.

\section{Discussion}

Conjunctival nevi in children should be given particular attention as the most common benign conjunctival neoplasms in this population (3). According to Shields et al. (3), conjunctival nevi account for $64 \%$ of all conjunctival neoplasms and are significantly more common than dermolipoma (5\%), lymphangioma $(3 \%)$ and capillary haemangioma $(3 \%)$. The number of publish reports to discuss the incidence of conjunctival lesions in children is limited. Furthermore, interpreting clinical data in children may be hindered due to the evolution of clinical features of the lesions over time. Most nevi are located within the perilimbal region of the palpebral conjunctiva, nasally or temporally, typically without corneal involvement. According to Shields et al. (2), the incidence of nevi affecting the cornea is below $1 \%$ and thus the presence of a lesion with corneal invoIvement may suggest a different diagnosis. Nevi located in the lacrimal caruncle, conjunctival fornix and palpebral conjunctiva are rare $(1,2,4)$.

Our results regarding the location of conjunctival nevi in children are comparable to large scale, comprehensive studies by Shields et al. (2) and Alkatan et al. (4). In our sample, the nevi were situated within the bulbar conjunctiva (81.51\%) and the lacrimal caruncle (18.49\%). Shields et al. (2) studied 410 patients with conjunctival pigmented lesions, $72 \%$ of which were located within the bulbar conjunctiva and $26 \%$ within the lacrimal caruncle or plica semilunaris. Alkan et al. (4) reported similar rates in 105 patients, with $83 \%$ located in the bulbar conjunctiva and $4 \%$ in the lacrimal caruncle.

Interestingly, the incidence of various histological types of conjunctival nevus in children enrolled in this study is not comparable to any other large-scale study. It is probably due to the fact that the available reports discuss the incidence of conjunc-

\begin{tabular}{|c|c|c|c|}
\hline Type of lesions & No. & Percent & The average age (year) \\
\hline \multicolumn{4}{|c|}{ Conjunctival nevus } \\
\hline melanocytic nevus (naevus conjuntivus melanociticus) & 61 & $41.78 \%$ & 9 \\
\hline compound nevus (naevus melanocyticus compositus) & 47 & $32.19 \%$ & 11 \\
\hline junctional nevus (naevus melanocticus junctionalis) & 23 & $15.75 \%$ & 10 \\
\hline subepithelial lesions (naevus subdermalis) & 1 & $0.68 \%$ & 7 \\
\hline TOTAL & 132 & $90.41 \%$ & 10 \\
\hline \multicolumn{4}{|c|}{ OTHER lesions } \\
\hline inflammatory process & 3 & $2.05 \%$ & 13 \\
\hline inflammatory process associated with fibrosis & 2 & $1.37 \%$ & 2 \\
\hline melanosis & 2 & $1.37 \%$ & 17 \\
\hline haemangioma & 1 & $0.68 \%$ & 9 \\
\hline lymphangioma & 1 & $0.68 \%$ & 4 \\
\hline subconjunctival haemorrhage & 1 & $0.68 \%$ & 8 \\
\hline conjunctival oedema with dilated lymphatic vessels & 1 & $0.68 \%$ & 12 \\
\hline fibrotic connective tissue & 1 & $0.68 \%$ & 16 \\
\hline increased melanocyte count & 1 & $0.68 \%$ & 8 \\
\hline lentigo & 1 & $0.68 \%$ & 12 \\
\hline TOTAL & 14 & $9.59 \%$ & 11 \\
\hline
\end{tabular}

Tab. I. Histological findings in 146 conjunctival lesions of 145 children.

Tab. I. Wynik badania histopatologicznego 146 zmian spojówki w grupie 145 badanych dzieci. 
tival pigmented lesions in adults rather than in children. In our study group, the most common type was melanocytic nevus $(41.78 \%)$, followed by compound nevus $(32.19 \%)$, junctional nevus $(15.75 \%)$ and a single case of subepithelial nevus $(0.68 \%)$. In the study by Alkatan et al. (4), the most common type was compound nevus (72\%), followed by subepithelial nevus (24\%) and junctional nevus (3\%). Similarly, Shields et al. (2) reported compound nevus as the most common $(70 \%)$, followed by subepithelial nevus (24\%) and junctional nevus (4\%). Therefore, the percentage of junctional nevi was higher and the percentage of subepithelial nevi was lower in our study as compared to the adult study groups mentioned above. This observation confirms the assumption made by Shields et al. (2) that junctional nevus is typical of younger age groups, while subepithelial nevus is more common in older age groups.

Optical coherence tomography (OCT) seems to be an accurate method for imaging superficial cysts (Fig. 4). Some authors associated the presence of cystic lesions on the surface of nevus with benign character of the lesion. According to various sources, cysts are identified in $60-70 \%$ of conjunctival lesions in adults and $65 \%$ in children $(2,3,4)$. There seems to be an agreement that conjunctival lesions need to be monitored over time (5). According to Sayyad et al. (6), the best method for monitoring conjunctival lesions is regular follow-up examination including photographs of the abnormal conjunctiva. If the lesion is stable with its size and colour unchanged, the lesion does not require an urgent surgical intervention as the malignant transformation is unlikely (6).

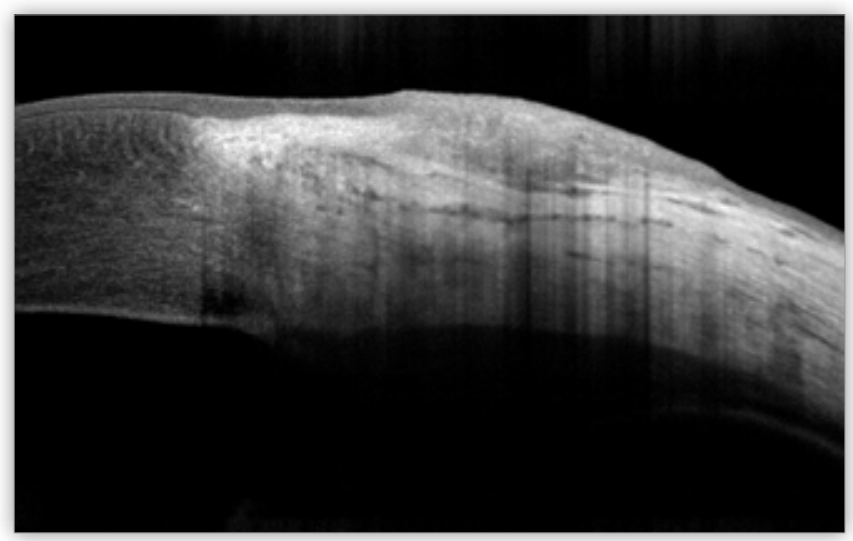

Fig. 4. Conjunctival nevus seen in the anterior segment optical coherence tomography (AS-OCT).

Ryc. 4. Obraz znamienia spojówki w badaniu OCT odcinka przedniego (AS-OCT).

Monitoring of the dynamics of morphological changes occurring in conjunctival pigmented lesions (i.e. altered pigmentation, size and vascularisation) may indicate the onset of a malignant transformation. Malignancy may also manifest as late onset conjunctival pigmented lesions, lesions located in the tarsal conjunctiva and conjunctival fornix as well as the absence of cysts on the surface of the lesion $(1,2,5,12)$. Monitoring a group of 410 patients with conjunctival pigmented lesions, Shield et al. noticed an increase of lesion size in $7 \%$ of cases, its altered colour in $5 \%$ of cases, darkening of conjunctival lesions in $13 \%$ cases and lesion growth in $8 \%$ of cases (2).

Haldar et al. (5) and Balaeva et al. (13) state that changes in lesion colour and size are normal only during pregnancy and in children during the growth period. Therefore, physiology may hinder close monitoring of conjunctival lesions children, so it is an imperative for practitioners to follow-up the lesions regularly with particular caution.

Colarossi et al. (8) observed that during growth and puberty, conjunctival lesions are often surrounded by inflammation, which mimics an increase in size and thus might raise a suspicion of malignancy. In the study by Aalkatan et al. (4), histological findings of conjunctival pigmented nevi were studied separately in a subgroup of patients below 20 years of age. The melanocytes were accompanied by inflammatory cells in $48 \%$ of those cases. In this study, 5 conjunctival lesions demonstrating clinical features of a pigmented nevus were histologically found to be of inflammatory origin.

The therapeutic approach to conjunctival nevi still remains debated. Although it seems extremely difficult to determine the time point, when watchful waiting needs to cease in favour of surgical intervention, such decision remains crucial to prevent malignancy (13). Sayyad et al. (6) postulate that alongside the nevus growth and altered coloration which indicate malignancy, the indications for surgery also include aesthetic considerations and psychological wellbeing of a patient. In line with the above, Alkatan Hind M. et al. (4) reported aesthetic indications (38\%), no specific indication (33\%), growth of the observed lesion $(29 \%)$ and change in coloration of the nevus $(8 \%)$ as the main causes of surgical intervention.

Currently, the most effective diagnostic management of conjunctival lesions seems to be surgical removal followed by post-operative histological evaluation of the tissue specimen $(2,7)$. This seems a crucial step in differentiating between benign and malignant lesions. The incidence of malignant conjunctival melanoma is extremely low in children. According to several authors, conjunctival nevus undergoes malignant transformation in only $1 \%$ of cases $(1,3,8,9)$. There are only 29 reported cases of conjunctival melanoma in children aged 15 years or younger $(4,11,14,15)$, and only 9 cases have been well-documented and described in detail. Furthermore, there are only 2 reported cases of malignant conjunctival melanoma in children aged 10 years or younger $(14,15)$. Apart from that, there are also 4 case reports of conjunctival melanoma secondary to conjunctival pigmented nevus. The number of studies reflects the low incidence of this malignancy in children. Since the reported follow-up periods after surgical removal of conjunctival melanoma in children were particularly short, the prognosis or survival data is significantly limited.

There were no cases of malignancy in our study group. This seems to be in accordance with the reports stating that such lesions are extremely rare in children. Nevertheless, the significance of monitoring patients with conjunctival pigmented lesions and timely clinical decision making to intervene should not be underestimated.

\section{Conclusions}

Although conjunctival pigmented lesions in children are usually benign, regular follow-up and close monitoring are required. Surgical removal of conjunctival pigmented lesions is a method of choice to prevent potential malignant transformation. Histological evaluation of lesions after a total resection enable ruling out malignancy. 


\section{References:}

1. Kanski JJ, Bowling B: Okulistyka kliniczna. Elsevier Urban \& Partner, Wrocław 2013; wydanie IV polskie; 472-478.

2. Shields CL, Fasiuddin AF, Mashayekhi A, Shields JA: Conjunctival nevi: clinical features and natural course in 410 consecutive patients. Arch Ophthalmol. 2004; 122(2): 167-175.

3. Shields CL, Shields JA: Conjunctival tumor in children. Curr Opin Ophthalmol. 2007; 18(5): 351-360.

4. Alkatan HM, Al-Arfaj KM, Maktabi A: Conjunctival nevi: clinical and histopatologic features in a Saudi population. Ann Saudi Med. 2010; 30(4): 306-312.

5. Haldar S, Leyland M: Spontaneous regression of a conjunctival naevus. Case Report 2016: bcr2016216066.

6. Sayyad FF, Karp CL, Scott IU, Fekrat S: Conjunctival Pigmented Lesions: Diagnosis and Menagment. EyeNet. 2013; (11): 35-36

7. Jovanovic P, Mihajlovic M, Djordjevic-Jocic J, Vlajkovic S, Cekic S, Stefanovic V: Ocular melanoma: an overview of the current status. Int j Clin Exp Pathol. 2013; 15, 6(7): 1230-1244.

8. Colarossi C, Milazzo M, Paglierani M, Massi D, Memeo L, Canzonieri V: $A$ juvenile case of conjunctival atypical nevus. Diagn Pathol. 2013; 22, 8: 64.

9. Shields CL, Kels JG, Shields JA: Melanoma of the eye: Revealing hidden secrets, one at a time. Clinics in Dermatology. 2015; 33: 183-196.
10. McDonnell JM, Carpenter JD, Jacobs P, Wan WL, Gilmore JE: Conjunctival melanocytic lesions in children. Ophthalmology. 1989; 96(7): 986-993.

11. Akor C, Greenberg MF, Polard ZF, Grossniklaus HE: Conjunctival melanoma in a child. J Pediatr Ophthalmol Strabismus. 2004; 41(1): 56-58.

12. Yazici B, Bilge AD, Yagci A, Nagadan F, Altintepe F: Melanocytic Nevus of Tarsal Conjunctiva. Balcan Med J. 2016; 33(4): 477-479 .

13. Balaeva RN, Kasimov EM: Nevi of conjunctiva as a risk factor of melanoma. Vestn Oftalmol. 2016; 132(3): 21-25.

14. Taban M, Traboulsi El: Malignant melanoma of conjunctiva in children: a review of the international literature 1965-2006. J Pediatr Ophthalmol Strabismus. 2007; 44(5): 277-282.

15. Brownstein S, Faraji H, Jackson WB, Font RL: Conjunctival melanoma in children: a clinicopathologic study of 2 cases. Arch Ophthalmol. 2006; 124(8): 1190-11193.

The paper was originally received 07.02.2019 (KO-00199-2019)/ Praca wpłynęła do Redakcji 07.02.2019 r. (K0-00199-2019) Accepted for publication 02.04.2019/ Zakwalifikowano do druku 02.04.2019 r.

Reprint requests to (Adres do korespondencji):

Klaudia Rakusiewicz, MD

Department of Ophthalmology

Children's Memorial Health Institute

Aleja Dzieci Polskich 20

05-077 Warszawa

e-mail: k.rakusiewicz@ipczd.pl 